\title{
Biocompatibility of fungi and essential oils or vegetable extracts: a bibliometric
}

\section{review}

Biocompatibilidade de fungos e óleos essenciais ou extratos vegetais: uma revisão bibliométrica

Biocompatibilidad de hongos y aceites esenciales o extractos de plantas: una revisión bibliométrica

Received: 08/26/2021 | Reviewed: 08/30/2021 | Accept: 09/01/2021 | Published: 09/05/2021

Clara Matte Borges Machado

ORCID: https://orcid.org/0000-0002-3652-6798

Universidade Federal do Paraná, Brazil

E-mail: claramattemachado@gmail.com

Ida Chapaval Pimentel

ORCID: https://orcid.org/0000-0002-1840-1748

Universidade Federal do Paraná, Brazil

E-mail: ida@ufpr.br

\begin{abstract}
Duponchelia fovealis is an agricultural pest that causes great losses in strawberry plantations. As an alternative to traditional chemical insecticides, entomopathogenic fungi (EPF) are used to control this pest. One way to increase the effectiveness of these EPF is by combining them with plant extracts or essential oils (EOs). We carried out a literature review in the Web of Science database using Bibliometrix (version 4.0.0. - R free software tool). Our purpose was to analyze data on the use of EOs or plant extracts with microorganisms to control pests, and observe research trends on this topic. Between 1994 and 2020, 112 articles were published, with the Egyptian Journal of Biological Pest Control as the most outstanding journal. The country with the greatest number of publications on the topic in the analyzed period was Brazil $(n=38)$, followed by India $(n=26)$ and the United States $(n=20)$. Keywords that stood out the most were compatibility, entomopathogenic fungi, Beauveria bassiana, biological control, Azadirachta indica, silver nanoparticles, entomopathogenic fungus, Metarhizium anisopliae, neem, and biocompatibility. Although this research field is growing, no record of a link between EPF and EOs or "plant extracts to control Duponchelia fovealis" was found.
\end{abstract}

Keywords: Bibliometric review; Entomopathogenic fungi; Essential oils; Vegetable extracts.

\section{Resumo}

Duponchelia fovealis é uma praga agrícola que causa grandes perdas nas plantações de morango. Como alternativa aos inseticidas químicos tradicionais, fungos entomopatogênicos (EPFs) são utilizados no controle dessa praga. Uma forma de aumentar a eficácia desses EPFs é combinando-os com extratos vegetais ou óleos essenciais (OE). Foi realizada uma revisão da literatura na base de dados Web of Science por meio do Bibliometrix (versão 4.0.0. ferramenta de software livre R). Nosso objetivo foi analisar dados sobre o uso de OE ou extratos vegetais com microrganismos para o controle de pragas e observar tendências de pesquisas sobre o tema. Entre 1994 e 2020,112 artigos foram publicados, sendo o Egyptian Journal of Biological Pest Control o periódico de maior destaque. O país com maior número de publicações sobre o tema no período analisado foi o Brasil $(\mathrm{n}=38)$, seguido da Índia $(\mathrm{n}=26)$ e dos Estados Unidos $(\mathrm{n}=20)$. As palavras-chave que mais se destacaram foram compatibilidade, fungos entomopatogênicos, Beauveria bassiana, controle biológico, Azadirachta indica, nanopartículas de prata, fungo entomopatogênico, Metarhizium anisopliae, neem e biocompatibilidade. Embora este campo de pesquisa esteja crescendo, nenhum registro de uma ligação entre EPFs e EOs ou "extratos de plantas para controlar Duponchelia fovealis" foi encontrado.

Palavras-chave: Revisão bibliométrica; Fungos entomopatogênicos; Óleos essenciais; Extratos vegetais.

\section{Resumen}

Duponchelia fovealis es una plaga agrícola que causa grandes pérdidas en las plantaciones de fresa. Como alternativa a los insecticidas químicos tradicionales, se utilizan hongos entomopatógenos (EPFs) para controlar esta plaga. Una forma de aumentar la eficacia de estos EPFs es combinándolos con extractos de plantas o aceites esenciales (AE). Realizamos una revisión de la literatura en la base de datos Web of Science utilizando Bibliometrix (versión 4.0.0. herramienta de software libre R). Nuestro propósito fue analizar datos sobre el uso de AE o extractos de plantas con microorganismos para el control de plagas y observar las tendencias de investigación sobre este tema. Entre 1994 y 2020, se publicaron 112 artículos, siendo la Egyptian Journal of Biological Pest Control la revista más destacada. El país con mayor número de publicaciones sobre el tema en el período analizado fue Brasil $(\mathrm{n}=38)$, seguido de India (n 
= 26) y Estados Unidos $(n=20)$. Las palabras clave que más destacaron fueron compatibilidad, hongos entomopatógenos, Beauveria bassiana, control biológico, Azadirachta indica, nanopartículas de plata, hongo entomopatógeno, Metarhizium anisopliae, neem y biocompatibilidad. Aunque este campo de investigación está creciendo, no se encontró ningún registro de un vínculo entre EPF y EO o "extractos de plantas para controlar Duponchelia fovealis".

Palabras clave: Revisión bibliométrica; Hongos entomopatógenos; Aceites esenciales; Extractos vegetales.

\section{Introduction}

The strawberry is a fruit with high added value. Nonetheless, strawberry crops are susceptible to attack by several pests, such as the crown caterpillar Duponchelia fovealis Zeller (Lepidoptera: Crambidae) (Zawadneak et al., 2017). In an attempt to control this pest, pesticides have been used indiscriminately, resulting in an accumulation of these substances in the fruit (EWG, 2019). Biocontrol agents represent an ecological alternative to chemical insecticides (Xu \& Hu, 2020). In this regard, the use of entomopathogenic fungi (EPF) is a viable strategy for integrated pest management (IPM) (Gonzalez et al., 2016), with proven efficacy in the control of D. fovealis (Amatuzzi et al., 2018; Amatuzzi, Poitevin, Poltronieri, Zawadneak \& Pimentel, 2018; Poitevin, Porsani, Poltronieri, Zawadneak \& Pimentel, 2018).

However, another promising management strategy is the use of essential oils (EOs) or plant extracts (Isman, 2000). An EO is defined as the product obtained through hydrodistillation, steam distillation, or dry distillation of a crude vegetable source (ISO, 2013), whereas the vegetable extract is described as the product acquired by treating a natural raw material with one or more solvents (ISO, 2013).

The study of joint action between EPF and EOs or vegetable extracts can help pest control (Diniz et al., 2020) by increasing the efficiency of control and decreasing the amount of chemical pesticides used (Halder, Rai \& Kodandaram, 2013). Accordingly, the present review aimed to analyze the body of literature published between 1941 and 2020 that focused on the combined action of EOs or plant extracts and fungi to combat pests.

\section{Methodology}

The bibliometric tool Bibliometrix, version 4.0.0. (R free software tool) was used to analyze the papers published on this topic since they promote a quantifying analysis of literature data (Zupic \& Čater, 2015). For this review, we chose the Web of Science database as it is the most traditional and oldest indexing database (Vieira \& Gomes, 2009). Therefore, on January 19, 2021, a search was carried out using the keywords TS=(compatibility AND (essential oil OR extract) AND fungi), in which the defined period was 1941 until the research date $(01 / 19 / 2021)$.

We found a total of 112 results. After reading the abstracts of all the documents, 91 publications were excluded. The exclusion criteria were: (i) not an original article document; (ii) not addressing the combination of EOs or extracts with fungi to combat pests. Consequently, 21 articles were selected for full reading.

\section{Results}

The bibliographical analysis showed that 112 articles were published between 1994 and 2020 (Figure 1). The journal Egyptian Journal of Biological Pest Control stood out the most (Figure 2). 
Figure 1 - Number of annual publications on biocompatibility between essential oils or plant extracts and fungi between 1994 and 2020, with data obtained by bibliometrics.

\section{Annual Scientific Production}

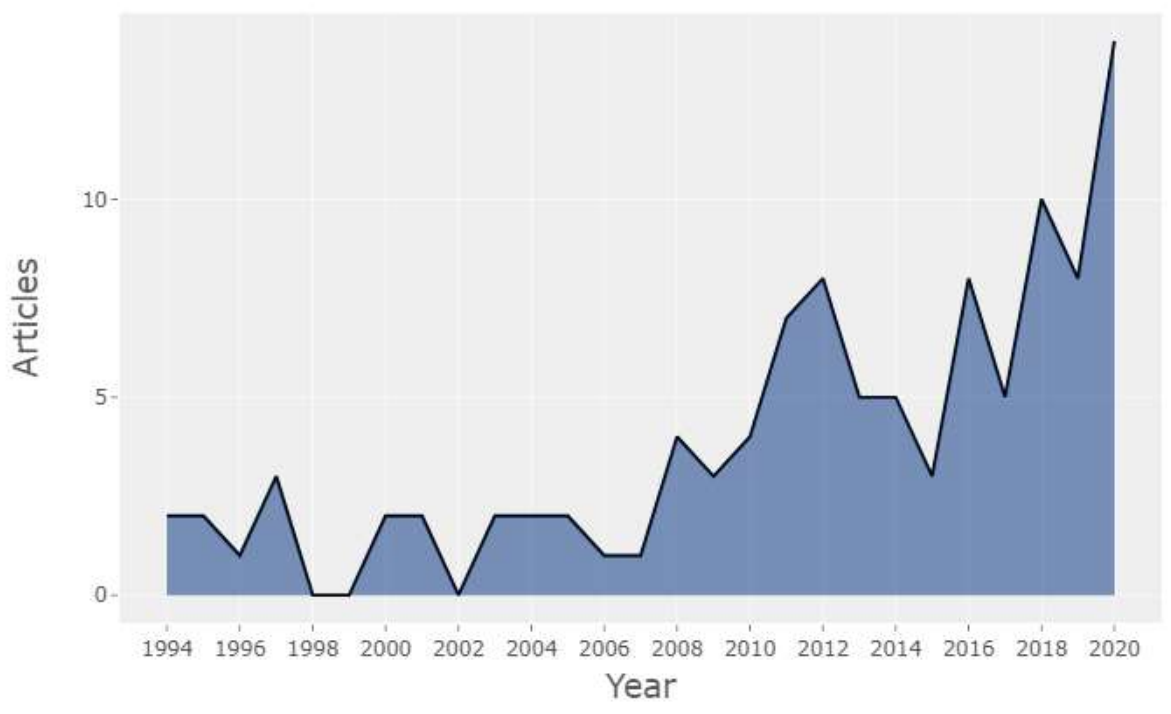

Source: Bibliometrix package (2021).

Here, it is noticeable the growing number of documents on this subject published since 2015, approximately. With this data, we can affirm that the field of combined action between fungi and essential oils or plant extracts is ascending in the academic community.

Figure 2 - Most relevant periodicals in publications on biocompatibility between essential oils or plant extracts and fungi between 1994 and 2020, with data obtained by bibliometrics.

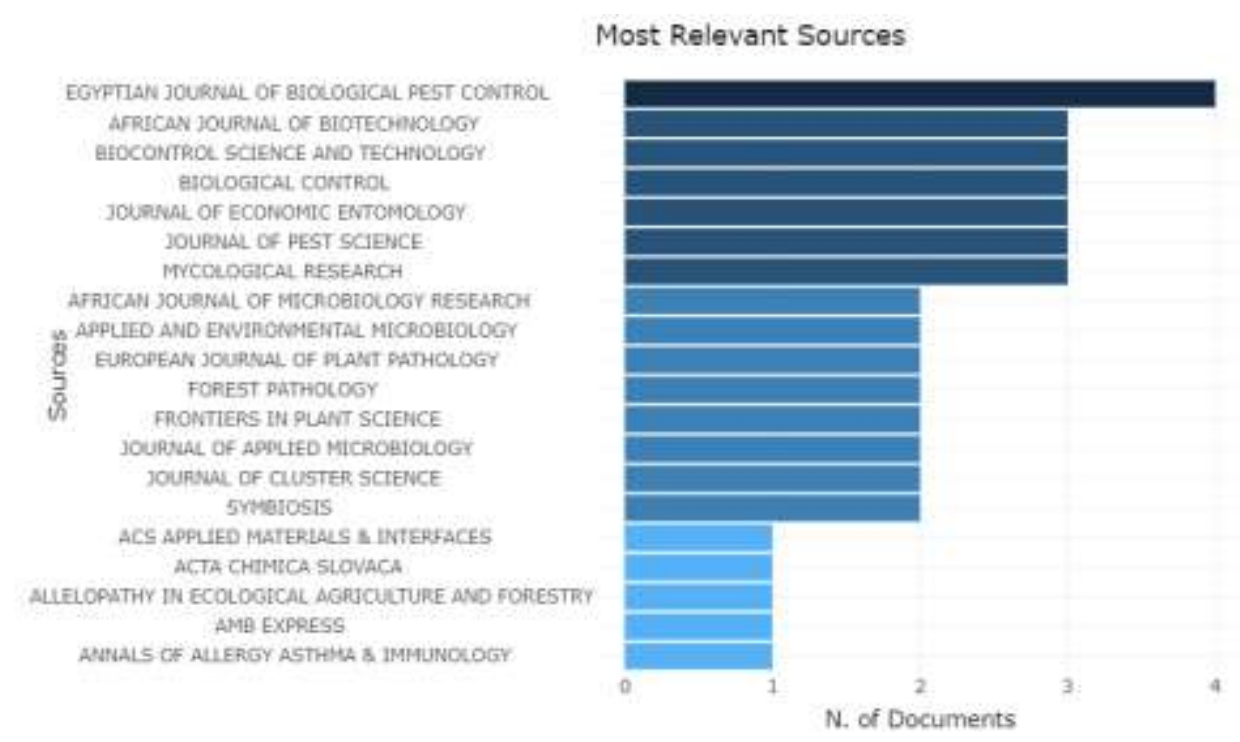

Source: Bibliometrix package (2021).

Observing the figure above, it is possible to affirm that the Egyptian Journal of Biological Pest Control is the most outstanding in this subject since it was the source that published the largest number of documents. 
Figure 3 - Keywords used most in articles on compatibility between essential oils or plant extracts and fungi between 1994 and 2020, with data obtained by bibliometrics.

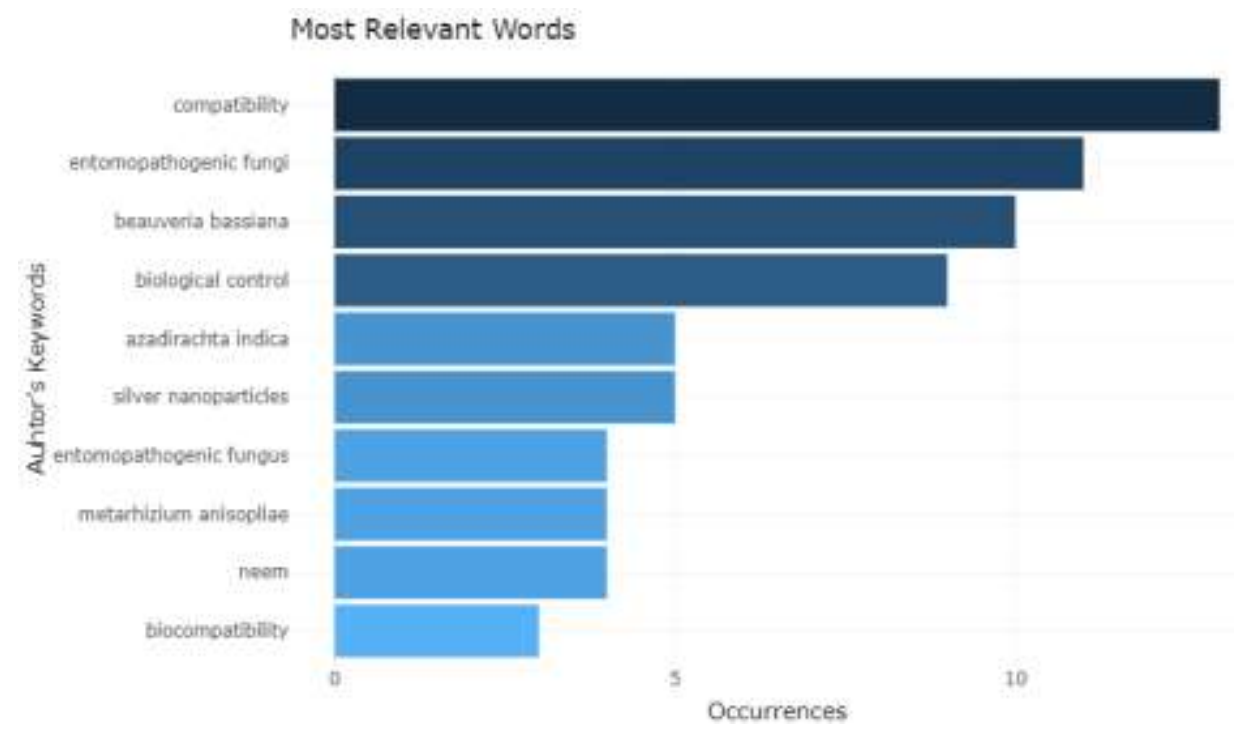

Source: Bibliometrix package (2021).

With this figure, we can observe that the keywords that stood out the most were "compatibility," "entomopathogenic fungi," "Beauveria bassiana," "biological control," “Azadirachta indica," "silver nanoparticles," “entomopathogenic fungus," "Metarhizium anisopliae," "neem," and "biocompatibility".

Figure 4 - Dynamics of keywords in publications on compatibility between essential oils or plant extracts and fungi between 1994 and 2020, with data obtained from bibliometrics.

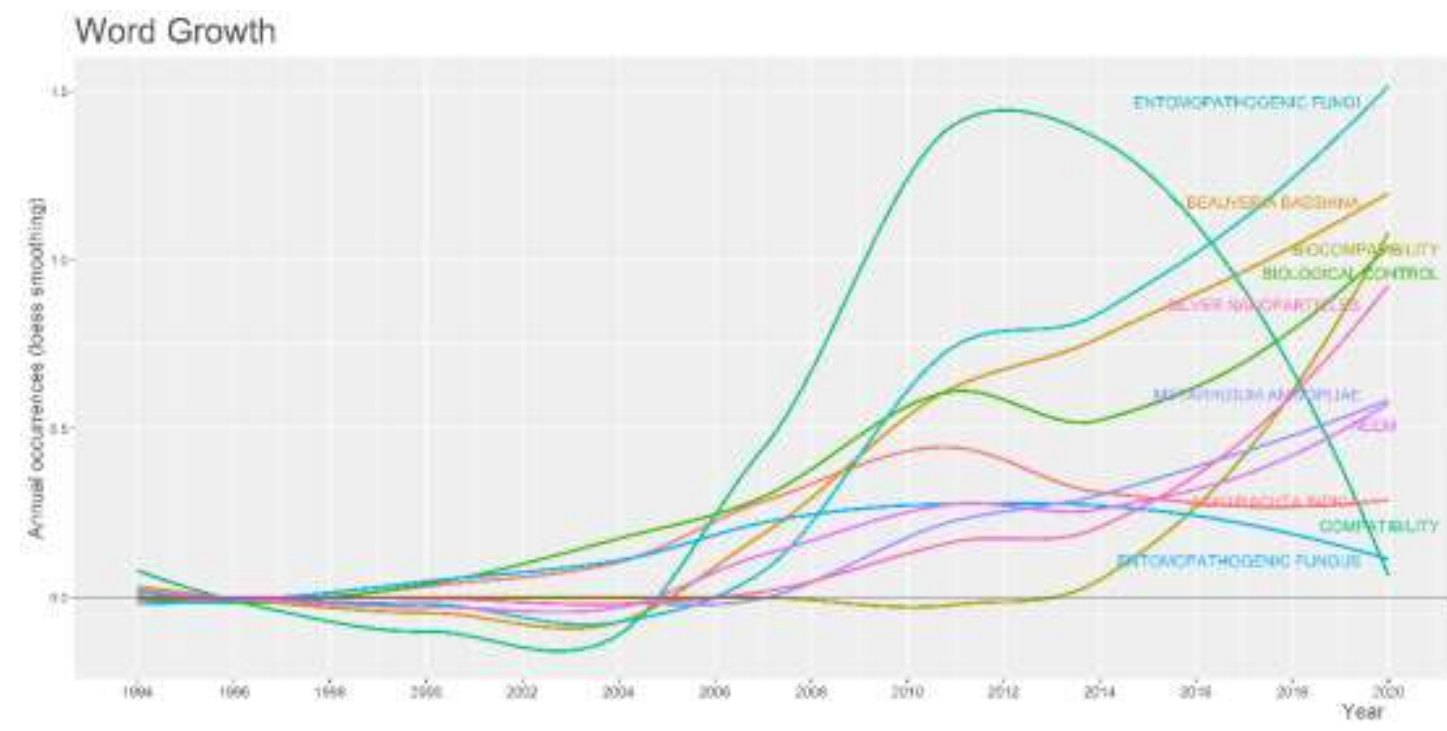

Source: Bibliometrix package (2021).

The figure presented above shows that the use of "compatibility" as a keyword is descending, however, the use of "biocompatibility" is ascending. This suggests that the two words are not synonyms and that the use of one is preferred in comparison to the other.

In addition, the five countries that published the greatest number of articles are Brazil $(n=38)$, followed by India $(n=26)$, the United States $(n=20)$, China $(n=19)$, and Pakistan $(n=14)$. 


\section{Discussion}

The bibliographic analysis allowed us to select 21 articles for full reading. After this step, an additional five articles were excluded as they did not describe the combination of fungi and EOs or plant extracts to combat pests. Therefore, the main points of the 16 selected documents are presented below.

Rehman et al. (2020) analyzed the compatibility of neem (Azadirachta indica), eucalyptus (Eucalyptus globulus), and tobacco (Nicotidiana tabacum) extracts with B. bassiana in combating the caterpillar stage of the beetle Tribolium castaneum. The authors found that higher caterpillar mortality was achieved with the combined treatment between B. bassiana and the extracts. For example, $71 \%$ mortality was achieved with combined treatment between B. bassiana and 5\% neem extract.

Sosa et al. (2020) studied the compatibility between EOs of oregano (Origanum vulgare) and anise (Pimpinella anisium) with Purpureocillium lilacinum (nematophagous fungus) on combating the nematoid Nacobbus aberrans. The most expressive mortality (86\%) was reached after the application of anise EO (0.02\%) with P. lilacinum.

Farooq, Atta, Gogi, Arif e Arain (2020) evaluated the mortality of the caterpillar of the pink bollworm Pectinophora gossypiella after the application of neem extract (A. indica) with three EPF (B. bassiana, M. anisopliae, and Verticillium lecanii). The highest mortality $(74.67 \%)$ was found with the combined application of the three EPF and neem extract at $5 \%$.

Diniz et al. (2020) studied the effects of Fusarium caatingaense with tobacco (N. tabacum) and brazilwood (Paubrasilia enchinata) extracts against the cochineal Dactylopius opuntiae. The highest pest mortality (98.7\%) was achieved by applying F. caatingaense URM 6779 variant and 10\% aqueous neem extract.

Velez et al. (2019) verified the potential mortality achieved through joint treatment of Fusarium incarnatum-equiseti, Chenopodium embrosioides (mastruz) and Enterolobium contortisiliquum (monkfish) extracts in combating D. opuntiae. Their study showed no significant increase in mortality of D. opuntiae when treatment was performed using fungus with extracts, compared to treatment using fungus alone. According to the authors, two treatments should be carried out in the field (URM6777 with aqueous extract of E. contortisiliquum 5\% and URM6779 with aqueous extract of E. contortisiliquum 5\%) since they caused relatively high mortality to the pest in their experiments $(70.34 \%$ and $73.64 \%$, respectively).

Ali et al. (2018) assessed the mortality of the English Grain Aphid Sitobion avenae when a solution of B. bassiana and M. anisopliae with neem (A. indica) and eucalyptus (Eucalyptus camaldulensis) extract at $7 \%$ was administered. The highest mortality of S. avenae (87\%) was obtained with a solution of B. bassiana and E. camaldulensis extract.

Jaber, Araj e Qasem (2018) evaluated the compatibility of B. bassiana and Metarhizium brunneum with plant extracts from Calotropis procera and Inula viscosa to combat the whitefly Bemisia tabasi. The researchers stated that all formulations (fungus, extract, and fungus with extract) resulted in pest mortality, although mortality was not necessarily increased by the combination of the plant extract with the fungus. The most significant mortality rate $(65.3 \%)$ was achieved using the combination of B. bassiana and C. procera.

Vásquez, Velandia e Jiménez (2018) studied the mortality of Raoiella indica using a solution of Isaria fumosorosea and B. bassiana with chrysanthemum extract (Chrysanthemum cinerariifoliu). The authors observed a toxic effect on the pest caused by the joint treatment of plant extracts with fungi, and this toxicity increased proportionally with the increase in the concentration of plant extracts. However, the highest mortality (100\%) occurred with the application of plant extract alone.

Nana, Ekesi, Nchu e Maniania (2016) assessed the compatibility of M. anisopliae with the extract of Calpurnia aurea in combating the zebra tick Rhipicephalus pulchellus. The concentrations of extract tested in their study were $1.25 \%, 2.5 \%$, $5 \%$, and $10 \%$, and the highest mortality was found in are the larval stage of R. pulchellus, in many cases reaching up to $100 \%$.

Santos, Oliveira, Da Costa, Tiago e De Oliveira (2016) studied the mortality of D. opuntiae through the joint application of Fusarium incarnatum-equiseti and plant extracts of Ricinus communis and Poincianella pyramidalis. Corrected mortality of $100 \%$ was obtained when F. incarnatum-equiseti URM6778 and 5\% R. communis were administered. 
Zibaee, Bandani e Sendi (2013) determined the compatibility of B. bassiana with extracts of two medicinal plants (Artemisia annua and Lavandula stoechas) in combating the larvae of the fall webworm Hyphantria cunea. The highest mortality $(76 \%)$ was reached by combining B. bassiana and A. annua at $0.5 \%$.

Halder, Rai e Kodandaram (2013) evaluated the mortality of Phenacoccus solenopsis (cotton mealybug), Aphis craccivora (cowpea aphid), Lipaphis erysimi (mustard aphid), and Dysdercus cingulatus (red cotton stainer) through the combined application of neem EO (A. indica) and microorganisms (B. bassiana, M. anisopliae, V. lecanii, and Pseudomonas fluorescens). EO solutions with fungus caused higher mortality of P. solenopsis than the fungal solution alone, with the highest mortality $(86.23 \%)$ achieved when V. lecanii solution and 5\% neem oil were administered at the 1:1 proportion.

Nana et al. (2012) studied the compatibility between M. anisopliae and C. aurea extract in combating the brown ear tick Rhipicephalus appendiculatus. The pest mortality was higher in combined treatments of extract and fungus compared to each alone. The mortality rate of R. appendiculatus after the combined treatment of extract and fungus varied according to the pest stage: $100 \%$ for larvae, $74.8-79.1 \%$ for nymphs, and $68.9-74.1 \%$ for adults.

Vergel, Bustos, Rodríguez e Cantor (2011) evaluated the mortality of the spider mite Tetranychus urticae when garlic (Phytoseiulus persimilis) and pepper extract (Neoseiulus carlifornicus) extract were applied together with B. beauveria and Paecilomyces fumosoroseus. They found no significant difference in mortality between treatments performed in the laboratory ( $\mathrm{p}>0.05)$. However, P. persimilis alone showed higher mortality under controlled greenhouse conditions than the other treatments (90.1\% efficiency after 14 days).

Sousa et al. (2011) studied the synergistic effect of B. bassiana with Melia azedarach extract in combating Rhipicephalus microplus (bovine pest). The treatment that caused more toxic effects to the pest was B. bassiana and M. azedarach at $0.25 \%$, which led to a decrease in engorged females from $233 \pm 82$ (control) to $129 \pm 70$ (with treatment).

Islam, Olleka e Ren (2010) analyzed the compatibility of B. bassiana with neem (A. indica) in the fight against the sweetpotato whitefly Bemisia tabaci. According to the authors, some concentrations of neem (above 5\%) were not compatible with the fungus, but compatibility was achieved with neem at $1 \%$, and there was an increase in mortality (88.25\%) with a conidial solution at $1 \times 108$ conidia/ml.

Observing the data presented above, Brazil was the country that published the most on biocompatibility between EOs or plant extracts and fungi between 1994 and 2020. Corroborating this result, $25 \%$ of the articles (four) were published by Brazilian correspondents among the 16 selected for full reading (Diniz et al., 2020; Velez et al., 2019; Santos, Oliveira, Da Costa, Tiago \& De Oliveira, 2016 and Sousa et al., 2011). On the other hand, only one article was published with a correspondent from India (Halder, Rai \& Kodandaram, 2013), diverging from the bibliometric results. None of the 16 documents had a US correspondent, also diverging from the data shown. Only one article had a correspondent from China (Islam, Olleka \& Ren, 2010), which also differs from the data. Finally, three articles had Pakistani counterparts (Rehman et al., 2020; Farooq, Atta, Gogi, Arif \& Arain, 2020 and Ali et al., 2018), also contrasting with the results obtained.

Figure 1 shows that work on biocompatibility between EOs or plant extracts and fungi has increased since 1994. In line with this result, all 16 articles selected were published between 2010 and 2020 (Diniz et al., 2020; Halder, Rai \& Kodandaram, 2013; Rehman et al., 2020; Sosa et al., 2020; Velez et al., 2019; Ali et al., 2018; Jaber, Araj \& Qasem, 2018; Vásquez, Velandia, Jiménez \& Velastegui, 2018; Nana, Ekesi, Nchu \& Maniania, 2016; Santos, Oliveira, Da Costa, Tiago \& De Oliveira, 2016; Zibaee, Bandani \& Sendi, 2013; Nana et al., 2012; Vergel, Bustos, Rodríguez \& Cantor, 2011; Sousa et al., 2011 And Islam, Olleka \& Ren, 2010), showing that this subject is gaining ground in the scientific community.

Furthermore, the journal that stood out between 1994 and 2020 was the Egyptian Journal of Biological Pest Control (Figure 2), with four indexed documents in this period. Among the 16 selected documents, three of them were published in this journal (Rehman et al., 2020; Farooq, Atta, Gogi, Arif \& Arain, 2020 and Ali et al., 2018). 
Figure 3 depicts "compatibility" as the most used keyword, and "biocompatibility" as the least used. However, according to Figure 4, the use of "compatibility" as a keyword has decreased, while "biocompatibility" has increased in the same period. Among the 16 studies analyzed, two had "compatibility" as a keyword (Vergel, Bustos, Rodríguez \& Cantor, 2011) and (Islam, Olleka \& Ren, 2010), and none had "biocompatibility." Although this data is not in agreement with the results shown in Figure 4, it is in line with Figure 3.

We can also affirm that the use of the keyword "EPF" increased in the observed period (1994-2020) (Figure 4). Considering that the keywords reflect the content of the research, following this data, all 16 articles worked with EPF (Diniz et al., 2020; Halder, Rai \& Kodandaram, 2013; Rehman et al., 2020; Sosa et al., 2020; Velez et al., 2019; Ali et al., 2018; Jaber, Araj \& Qasem, 2018; Vásquez, Velandia, Jiménez \& Velastegui, 2018; Nana, Ekesi, Nchu \& Maniania, 2016; Santos, Oliveira, Da Costa, Tiago \& De Oliveira, 2016; Zibaee, Bandani \& Sendi, 2013; Nana et al., 2012; Vergel, Bustos, Rodríguez \& Cantor, 2011; Sousa et al., 2011 And Islam, Olleka \& Ren, 2010).

The use of the keyword "Beauveria bassiana" as well as the use of this microorganism in the studies analyzed also increased in the period observed (1994-2020) (Figure 4). Of the 16 studies, 10 used B. bassiana (Halder, Rai \& Kodandaram, 2013; Rehman et al., 2020; Farooq, Atta, Gogi, Arif \& Arain, 2020; Ali et al., 2018; Jaber, Araj \& Qasem, 2018; Vásquez, Velandia \& Jiménez, 2018; Zibaee, Bandani \& Sendi, 2013; Vergel, Bustos, Rodríguez \& Cantor, 2011; Sousa et al., 2011 and Islam, Olleka \& Ren, 2010), and five of them were published from 2018 onward (Rehman et al., 2020; Farooq, Atta, Gogi, Arif \& Arain, 2020; Ali et al., 2018; Jaber, Araj \& Qasem, 2018 and Vásquez, Velandia, Jiménez \& Velastegui, 2018). Therefore, we can assume that its use has been increasing, as shown in Figure 4.

Figure 4 also shows that the use of the keyword "Metarhizium anisopliae" increased between 1994 and 2020, which corroborates the number of studies that analyzed this microorganism. Among the 16 articles, five used Metarhizium anisopliae (Halder, Rai \& Kodandaram, 2013; Farooq, Atta, Gogi, Arif \& Arain, 2020; Ali et al., 2018; Nana, Ekesi, Nchu \& Maniania, 2016 and Nana et al., 2012), and three of them were published as of 2016 (Farooq, Atta, Gogi, Arif \& Arain, 2020; Ali et al., 2018 and Nana, Ekesi, Nchu \& Maniania, 2016), evidencing its increased use.

The same figure shows that the use of "neem" as a keyword as well as its use in the analyzed works increased in the period studied (1994-2020). Of the 16 articles, five used "EO” or "plant extract of neem" (Halder, Rai \& Kodandaram, 2013; Rehman et al., 2020; Farooq, Atta, Gogi, Arif \& Arain, 2020; Ali et al., 2018 and Islam, Olleka \& Ren, 2010), three of which were published as of 2018 (Rehman et al., 2020; Farooq, Atta, Gogi, Arif \& Arain, 2020) and (Ali et al., 2018), indicating the increased use of this keyword.

Furthermore, Figure 4 shows that the use of "biological control" as a keyword increased between 1994 and 2020 , but only one article among the 16 had this term as a keyword (Farooq, Atta, Gogi, Arif \& Arain, 2020), although all documents read in full — except for one (Sousa et al., 2011)—were about combating an agricultural pest.

\section{Conclusion}

Bibliometric methods allowed us to carry out a comprehensive analysis and identify that biological control is one of the expanding lines of research in the scientific community. In recent years, the attention of researchers has focused on the use of fungi, predator agents, and parasites that can control D. fovealis.

However, there is a lack of studies on the applicability of these agents with EOs or plant extracts to combat this pest. Therefore, we suggested that this subject be explored in future studies, as it represents a sustainable and safe strategy in controlling the European pepper moth from an environmental perspective. 


\section{References}

Ali, S., Farooqi, M. A., Sajjad, A., Ullah, M. I., Qureshi, A. K., Siddique, B., Waheed, W., Sarfraz, M., \& Asghar, A. (2018). Compatibility of entomopathogenic fungi and botanical extracts against the wheat aphid, Sitobion avenae (Fab.) (Hemiptera: Aphididae). Egyptian Journal of Biological Pest Control, 28(1), 1-6. https://doi.org/10.1186/s41938-018-0101-9.

Amatuzzi, R. F., Cardoso, N., Poltronieri, A. S., Poitevin, C. G., Dalzoto, P., Zawadeneak, M. A., \& Pimentel, I. C. (2018). Potential of endophytic fungi as biocontrol agents of Duponchelia fovealis (Zeller) (Lepidoptera: Crambidae). Brazilian Journal of Biology, 78(3), 429-435. https://doi.org/10.1590/15196984.166681 .

Amatuzzi, R. F., Poitevin, C. G., Poltronieri, A. S., Zawadneak, M. A. C., \& Pimentel, I. C. (2018). Susceptibility of Duponchelia fovealis Zeller (Lepidoptera: Crambidae) to soil-borne entomopathogenic fungi. Insects, 9(2). https://doi.org/10.3390/insects9020070.

EWG's 2021 Shopper's Guide to Pesticides in Produce | Dirty Dozen. (n.d.). https://www.ewg.org/foodnews/dirty-dozen.php

Farooq, M. A., Atta, B., Gogi, M. D., Arif, M. J., \& Arain, Q. A. (2020). Compatibility of entomopathogenic fungi and Azadirachta indica extract against the cotton pink bollworm, Pectinophora gossypiella (Saunders) (Lepidoptera: Gelechiidae) under controlled conditions. Egyptian Journal of Biological Pest Control. https://doi.org/10.1186/s41938-020-00260-x.

Diniz, A. G., Barbosa, L. F. S., Santos, A. C. da S., Oliveira, N. T. de, Costa, A. F. da, Carneiro-Leão, M. P., \& Tiago, P. V. (2020). Bio-insecticide effect of isolates of Fusarium caatingaense (Sordariomycetes: Hypocreales) combined to botanical extracts against Dactylopius opuntiae (Hemiptera: Dactylopiidae). Biocontrol Science and Technology, 30(4), 384-395. https://doi.org/10.1080/09583157.2020.1720601.

Gonzalez, F., Tkaczuk, C., Monica Dinu, M., Fiedler, Z., Vidal, S., Zchori-Fein, E., \& Messelink, G. J. (2016). New opportunities for the integration of microorganisms into biological pest control systems in greenhouse crops. Journal of Pest Science, 89, 295-311. https://doi.org/10.1007/s10340-016-0751-x.

Halder, J., Rai, A. B., \& Kodandaram, M. H. (2013). Compatibility of Neem Oil and Different Entomopathogens for the Management of Major Vegetable Sucking Pests. The National Academy of Sciences, 36(1), 19-25. https://doi.org/10.1007/s40009-012-0091-1.

Islam, M. T., Olleka, A., \& Ren, S. (2010). Influence of neem on susceptibility of Beauveria bassiana and investigation of their combined efficacy against sweetpotato whitefly, Bemisia tabaci on eggplant. Pesticide Biochemistry and Physiology, 98(1), 45-49. https://doi.org/10.1016/j.pestbp.2010.04.010.

Isman, M. B. (2000). Plant essential oils for pest and disease management. Crop Protection, 19(8-10), 603-608. https://doi.org/10.1016/S02612194(00)00079-X.

ISO, I. S. 9235: 2013 A. natural raw materials - vocabulary. (2013). ISO 9235:2013 - Aromatic natural raw materials -- Vocabulary. ISO, International Standard 9235: 2013 Aromatic Natural Raw Materials_-Vocabulary. https://www.iso.org/obp/ui/\#iso:std:iso:9235:ed-2:v1:en.

Jaber, L. R., Araj, S. E., \& Qasem, J. R. (2018). Compatibility of endophytic fungal entomopathogens with plant extracts for the management of sweetpotato whitefly Bemesia tabaci Gennadius (Homoptera: Aleyrodidae). Biological Control, 117, 164-171. https://doi.org/10.1016/j.biocontrol.2017.11.009.

Nana, P., Ekesi, S., Nchu, F., \& Maniania, N. K. (2016). Compatibility of Metarhizium anisopliae with Calpurnia aurea leaf extracts and virulence against Rhipicephalus pulchellus. Journal of Applied Entomology, 140(8), 590-597. https://doi.org/10.1111/jen.12289.

Nana, P., Maniania, N. K., Maranga, R. O., Boga, H. I., Kutima, H. L., \& Eloff, J. N. (2012). Compatibility between Calpurnia aurea leaf extract, attraction aggregation, and attachment pheromone and entomopathogenic fungus Metarhizium anisopliae on viability, growth, and virulence of the pathogen. Journal of Pest Science, 85(1), 109-115. https://doi.org/10.1007/s10340-011-0399-5.

Poitevin, C. G., Porsani, M. V., Poltronieri, A. S., Zawadneak, M. A. C., \& Pimentel, I. C. (2018). Fungi isolated from insects in strawberry crops act as potential biological control agents of Duponchelia fovealis (Lepidoptera: Crambidae). Applied Entomology and Zoology, 53(3), 323-331. https://doi.org/10.1007/s13355-018-0561-0.

Rehman, H. ur, Rasul, A., Farooqi, M. A., Aslam, H. M. U., Majeed, B., Sagheer, M., \& Ali, Q. (2020). Compatibility of some botanicals and the entomopathogenic fungus, Beauveria bassiana (Bals.), against the red flour beetle, Tribolium castaneum (Herbst) (Coleoptera: Tenebrionidae). Egyptian Journal of Biological Pest Control, 30(1). https://doi.org/10.1186/s41938-020-00329-7.

Santos, A. C. da S., Oliveira, R. L. S., da Costa, A. F., Tiago, P. V., \& de Oliveira, N. T. (2016). Controlling Dactylopius opuntiae with Fusarium incarnatumequiseti species complex and extracts of Ricinus communis and Poincianella pyramidalis. Journal of Pest Science, 89(2), 539-547. https://doi.org/10.1007/s10340-015-0689-4.

Sosa, A. L., Girardi, N. S., Rosso, C. L., Salusso, F., Etcheverry, M. G., \& Passone, M. A. (2020). In vitro compatibility of Pimpinella anisum and Origanum vulgare essential oils with nematophagous fungi and their effects against Nacobbus aberrans. Journal of Pest Science, 93, 1381-1395. https://doi.org/10.1007/s10340-020-01252-4.

Sousa, L. A. D., Pires Júnior, H. B., Soares, S. F., Ferri, P. H., Ribas, P., Lima, E. M., Furlong, J., Bittencourt, V. R. E. P., Perinotto, W. M. de S., \& Borges, L. M. F. (2011). Potential synergistic effect of Melia azedarach fruit extract and Beauveria bassiana in the control of Rhipicephalus (Boophilus) microplus (Acari: Ixodidae) in cattle infestations. Veterinary Parasitology, 175(3-4), 320-324. https://doi.org/10.1016/j.vetpar.2010.10.012.

Vásquez, C., Velandia, P., Jiménez, M., \& Velastegui, G. (2018). Efectividad in vitro del extracto etano del crisantemo y de hongos acaropatógenos en el control del ácaro rojo en las palmeras. Bioagro, 30(2), 135-144.

Velez, B. A. de A., Diniz, A. G., Barbosa, L. F. S., Santos, A. C. da S., da Costa, A. F., \& Tiago, P. V. (2019). Potential of Fusarium incarnatum-equiseti species complex isolates with Chenopodium ambrosioides and Enterolobium contortisiliquum extracts to control Dactylopius opuntiae. International Journal of Tropical Insect Science, 39(2), 131-138. https://doi.org/10.1007/s42690-019-00014-9. 
Research, Society and Development, v. 10, n. 11, e405101119874, 2021

(CC BY 4.0) | ISSN 2525-3409 | DOI: http://dx.doi.org/10.33448/rsd-v10i11.19874

Vergel, S. J. N., Bustos, R. A., Rodríguez, C. D., \& Cantor, R. F. (2011). Laboratory and greenhouse evaluation of the entomopathogenic fungi and garlicpepper extract on the predatory mites, Phytoseiulus persimilis and Neoseiulus californicus and their effect on the spider mite Tetranychus urticae. Biological Control, 57(2), 143-149. https://doi.org/10.1016/j.biocontrol.2011.02.007.

Vieira, E. S., \& Gomes, J. A. N. F. (2009). A comparison of Scopus and Web of science for a typical university. Scientometrics, 81(2), 587-600. https://doi.org/10.1007/s11192-009-2178-0.

Xu, X., \& Hu, X. (2020). The effect of aggregation of pathogen and biocontrol microbe propagules on biocontrol potential: a simple modelling study. Phytopathology Research, 2(1), 1-9. https://doi.org/10.1186/s42483-020-0047-1.

Zawadneak, M. A. C., Gonçalves, R. B., Poltronieri, A. S., Santos, B., Bischoff, A. M., Borba, A. M., \& Pimentel, I. C. (2017). Biological parameters of Duponchelia fovealis (Lepidoptera: Crambidae) reared in the laboratory on two diets. In European Journal of Entomology (Vol. 114, pp. 291-294). Czech Academy of Sciences. https://doi.org/10.14411/eje.2017.035.

Zibaee, I., Bandani, A. R., \& Sendi, J. J. (2013). Pathogenicity of Beauveria bassiana to fall webworm (Hyphantria cunea) (Lepidoptera: Arctiidae) on different host plants. Plant Protection Science, 49(4), 169-176. https://doi.org/10.17221/72/2012-pps.

Zupic, I., \& Čater, T. (2015). Bibliometric Methods in Management and Organization. Organizational Research Methods, 18(3), 429-472. https://doi.org/10.1177/1094428114562629. 